\title{
AESTHETICS AND THE PHILOSOPHY OF ART
}

JOHN PASSMORE

The Australian National University,

Camberra

What has aesthetics got to do with philosophy? Why is its teaching so often entrusted to philosophers? Why is it so often regarded as a branch of philosophy?

One possible answer is the cynical-sounding one that aesthetics has never got anywhere. That is why it is still left as a game for philosophers to play, unlike astronomy, biology, mathematics, economics, which have made discoveries, have developed systematic theories, and in that way have shaken themselves free from philosophy. We could express the same point rather more politely by saying that the real question in regard to any field of inquiry is why it is not now a part of philosophy rather than why it is i.e. how it came to break off as a separate science. Perhaps there are conditions for independence which aesthetics has so far failed to fulfil; perhaps some genius will come along and convert aesthetics into a fully independent subject - as Newton did with physics, or Adam Smith with economics, or Russell with mathematical logic.

The attempt to turn aesthetics into an independent science has been a recurrent one over the last hundred years; sometimes by diminishing it into a branch of some existing science, e.g. experimental psychology, sometimes by carving out for it an independent field. Thomas Munro in his Towards Science in Aesthetics (1955) quite confidently asserts that it is "now widely recognised that aesthetics is no longer a branch of speculative philosophy ... but part of the descriptive inquiry which seeks to find out and state the 
facts about works of art as a kind of observable phenomena, in relation to other phenomena of human experience, behaviour and culture." But although a good many people would applaud Munro's declaration of independence, articles la. belled 'aesthetics' continue to appear in philosophical journals, even in Mind. Is this because the various attempts to develop an independent aesthetics have in fact failed, or is there some reason why they are bound to fail, why aesthetics cannot cut itself off, as economics has done, from philosophy?

On the face of it, certainly, there do not seem to be any good grounds for supposing that philosophers, as such, are competent to settle disputes about works of art. Philosophers as a class are no better than other men at deciding whether a painting is beautiful or a tragedy is a good one. To this it might be replied that philosophy considers works of art at a more abstract level than this: asking not whether a painting is beautiful but in what its beauty consists, not whether a tragedy is good but in what the goodness of a tragedy consists. The case is parallel, it might be added, with that of truth. Philosophers are no better than other men at deciding what is true and what is not - a physicist will be far better than a philosopher if truths about electrical phenomena are in question. But this does not affect the philosopher's right, and, indeed, his duty, to talk about truth.

However, the two cases are not really comparable. For one thing, questions about truth arise inevitably out of the central concerns of philosophy - its interest in the nature of inquiry - as questions about the characteristics of works of art do not seem to do. Why should philosophers take a special interest in works of art, as they do not in stars, or in plants, or in articles of furniture?

Perhaps it would help to clarify the situation if we differentiate various levels at which it is possible to talk about works of art. Let us therefore distinguish between: 
(1) Judgments which assign critical predicates to particular works of art or to particular artists: 'King Lear is a great tragedy.' 'Stravinsky is a master of orchestration.'

(2) Judgements about specific art forms: 'Every great tragedy is concerned with treachery.' 'Painting captures the form of natural objects.' 'The nude in sculpture is always idealised.'

(3) Judgments about works of art in general: 'Every work of art signifies its content through its form.' 'Every work of art has a beginning, a middle and an end.' 'The Beauty of a work of art lies in its organic structure.'

(4) Judgments which assign peculiarly philosophical predicates either to works of art or to critical comments on works of art: " 'Beautiful' is a relational predicate." "The work of art which is the direct object of aesthetic appreciation is something over and above the perceptual object which immediately confronts us." "Aesthetic judgments are exhortations in disguise."

I propose to speak of modes of activity which employ statements of type (1) as criticism; type (2) as critical theory; type (3) as aesthetics; type (4) as the philosophy of art. I do not mean to suggest that in practice these types of judgment are sharply cut off from one another. The critical theorist has to defend his theories by making critical judgments about particular works of art; anyone who sets out to be an aesthetician cannot avoid forays into criticism and critical theory. In the opposite direction the critic may be driven into critical theory. We cannot say, of course, that he must have a critical theory. There were critics before there was critical theory, and inevitably so. Critical theory arises out of reflection on the mode in which the critic characterises works of art. But the critic may be forced to develop a literary theory in the attempt to defend his judgments.

That the literary critic need ever be driven into aesthetics, however, as distinct from critical theory, is by no means so 
obvious. It is sometimes said that judgments about particular works of art e.g. 'Macbeth is a good tragedy' can only be defended by falling back on a general theory of what it is to be a good work of art. Thus Harold Osborne in Aesthetics and Criticism, maintains that "A theory of the nature of artistic excellence is implicit in every assertion about works of art which is other than an autobiographical record." "But whereas if a critic says that "Macbeth fails because Macbeth is not a noble character," he does seem to be implicitly presuming a general literary theory, viz. that a good tragedy is always about noble characters, it is by no means so obvious that he is presuming anything whatever about works of art in general. It is at least a prima facie reply to his criticism if we can point to a tragedy which is not about noble characters but is none-the-less a good tragedy; but it is not even a prima facie reply that a good painting need not be about noble characters.

Perhaps there can be no good defences of literary criticism which do not presume a general literary theory -or, at least, a theory about a particular genre, or a particular type, of literary work. But it is quite another matter to suggest that literary criticism must rest upon aesthetics, upon a theory which applies as much to painting as to literature. To judge that a novel's literary value lies in its truth to life is certainly not to commit ourself to the judgment that it even makes sense to talk about the verisimilitude of a symphony or of a cathedral or of a vase.

As for literary theory, that can be defended or attacked by reference to critical judgments. We do not need to work out an aesthetics before we can decide whether or not all good tragedy is about noble characters. No doubt, one can imagine an attempt to demonstrate this proposition by deducing it from general aesthetic propositions, by arguing, for example, that all good works of art arouse noble feelings;

1 Routledge and Kegan Paul, Ltd., London, 1955, p. 93 
that if a tragedy is to arouse noble feelings, it must be about noble characters; and so that a great tragedy must be about noble characters. But that is not even the natural, let alone the inevitable, way of defending such a hypothesis. If it is deductively derived, it would normally be from a theory of tragedy, not from aesthetics; and it is more likely not to be so derived, but defended or attacked by means of an analysis of apparent counter-examples.

For our immediate purposes, the vital distinction is between the first three types of inquiry - critical, criticaltheoretical, aesthetics - on the one hand and the philosophy of art on the other. The difference between philosophy of art and critical theory is exemplified in the work of Plato and Aristotle. Plato and Aristotle are often compared and contrasted as if they were making contributions to a single subject, aesthetics, but in fact (for the most part) Plato was interested in the philosophy of art, and Aristotle in literary theory.

Thus Plato was perhaps the first to discuss what has come to be called "The ontological status of works of art." Ordinary objects, he suggests in the Republic, are "copies" or "imitations" of eternal objects (the forms); works of art are copies of copies: they have the same ontological status as shadows or reflections. Suppose we object to this account of the matter by arguing that a novel is not a shadow or reflection since there is no object to cast it as a shadow or for it to reflect, or again that a building does not copy any other object - except perhaps some other building. What is being discussed in such instances is a purely philosophical thesis; to discuss it we need know practically nothing about works of art; the cheapest novelette could serve as an example quite as well as the noblest tragedy, or the ugliest bungalow would exemplify our point as well as the most magnificent work of architecture.

Secondly, Plato asked himself whether -as the Greeks had ordinarily believed - poets have any claim to be regarded as possessing a certain special sort of knowledge or 
wisdom. Starting from the presumption that man can be said to have knowledge only if he can give a rational account of why he says what he says, he concludes in such dialogues as the Ion that poets do not possess knowledge. This, without any doubt, is the sort of question in which a philosopher qua philosopher can very naturally interest himself. Traditionally the philosopher asks himself under what circumstances a man can properly profess to have knowledge; as a special case of this general problem he might well ask himself, for example, whether and in what way the novel could possibly add to our knowledge about human beings. But once more, he can answer that question without having any extensive acquaintance with literature, or any real interest in it. What interests him is how we could acquire knowledge by reading an imaginary story about an imaginary person-whether the person be Little Red Riding Hood or Ivan Karamazov.

Thirdly, Plato asks himself what part is played by art in human life and human society. This sort of question is not now commonly discussed by English speaking philosophers. ${ }^{2}$ But it is still a principal concern of continental philosophers. And we can say this much at least: even if it is not philosophy, it does not seem to be critical theory or aesthetics either; it would belong rather to a kind of theoretical sociology. To answer it we must certainly know something about the actual effects of looking at pictures and reading books.

Plato, then, although he makes occasional remarks which have a bearing on aesthetics or critical theory, is primarily a philosopher of art, as I understand that phrase. Aristotle, on the other hand, is a literary theorist. He sets out, so he tells us, to "treat of poetry in general, and of its several species"; to inquire what "is the proper effect of each, what construction of a fable, or plan, is essential to a good poem

2 But M. C. Beardsley devotes the last chapter in his Aesthetics (Harcourt, Brace and World, 1958) to precisely this issue. 
- of what, and how many, parts each species consists". (Poetics, Introduction). He includes, it is true, music under poetry, as was the Greek custom - perhaps because the song had been the normal form of both music and poetry. But he does not try to discuss painting, art and architecture in the same terms. He does not ask, for example, what fable a work of architecture contains; he is writing literary theory, not aesthetics. (Perhaps this is a tribute to his good sense.) He defends his views by detailed references to Greek writers. No philosopher with a negligible knowledge of literature could have written the Poetics. And, on the other side, except on an occasional point, Aristotle need not have been a philosopher to have written the Poetics, any more than he had to be a philosopher to write the Constitution of Athens.

So far, then, my conclusion can be put thus: there are certain questions raised by the arts which are essentially philosophical and the systematic philosopher will very naturally take an interest in them. However, the critic, the critical theorist, the aesthetician, is no more bound to have views about them than the physical scientist must have views about the ontological status of the electrons or the nature of induction. They together constitute the philosophy of art, not aesthetics.

A particular philosopher, such as Aristotle, may, because he happens to be more than ordinarily knowledgeable about works of art, act a critic, or a critical theorist, or an aesthetician, but there is no intrinsic reason why the philosopher should by any of these, and no reason, on the other side, why the critic, the critical theorist, the aesthetician, should be a philosopher.

Are there any other issues, except those raised by Plato, which belong to the philosophy of art? I shall mention two: they differ from Plato's questions in so far as they arise out of reflection, not on the work of art as such, but on critical comments on works of art. They are none the less, or the more, philosophical for that. 
Characteristically, the writings of critical theorists and aestheticians are heavily dependent on certain notions in which the philosopher has a peculiar interest; such notions as truth, as when works of literature are said to be true to life, or when architecture is said to be true to the material the architect employs; such notions as unity, form, necessity; such notions as purpose or organic structure, as fulfilling or not fulfilling intentions, as creation or imagination. These are all of them concepts about which philosophers may reasonably be expected to have something important to say. Even if chemists are muddled about some such concept as valency, it is unlikely that philosophers could do much to clear up their confusion, unless they are also fairly expert in chemistry. But a philosopher who is not very well acquainted with works of art - although he will certainly need to have some interest in them, just as the philosopher of mathematics needs to have some interest in mathematics may yet be able to throw light on puzzles about the notion of 'artistic truth' or about the relations between form and content, merely as an application of his general views about truth or about content. To talk about some such concept as 'artistic truth' is in a very direct sense to be 'doing philosophy'. One sees this even in the Poetics. A philosopher's ears prick up, as it were, when Aristotle starts talking about 'improbabilities' and 'impossibilities' in tragedies.

The philosopher is particularly interested in differences between different kinds of discussion, and in the ways in which issues are settled in them. Discussions about works of art are peculiarly difficult from this point of view. On the one side, the participants in them normally support their assertions with reasons - 'that is a good painting because...'; on the other side, these 'reasons' often seem to be related in a rather odd way to the judgments they support. This, certainly, is a matter for philosophical investigation.

There are good grounds, therefore, for supposing there to be a form of inquiry which can properly be described as 
'the philosophy of art', parallel in form to the philosophy of mathematics or the philosophy of science. One can ask what is the ontological status of a work of art, just as one can ask the same question about numbers or electrons; whether and how art, or whether and how mathematics or physical science, give us knowledge; how conclusions about works of art or how mathematical conclusions or scientific conclusions, are established; what 'true' means in critical com. ments on literature or what 'proof' means in critical comments on mathematics or what 'verified' means in crit. ical comments on science. Just as a philosopher who is not a particularly competent mathematician or scientist may yet throw light on problems in the philosophy of mathematics or science; so a philosopher who is not a particularly com. petent critic may nevertheless contribute to the philosophy of art. But in either of these cases, or course, the major contributions are to be expected from philosophers who have a more than average acquaintance with the field 'the philo. sophy of which they are investigating.

Whe must now ask ourselves whether there are equally as good reasons, once it has been distinguished from the philo. sophy of art, for supposing that aesthetics is a fruitful field of inquiry and one on which philosophy can be expected to throw light. ${ }^{3}$

Historically speaking, there are two major views about the subject-matter of aesthetics: the first, that it is concerned with 'the beautiful' and the second, that it is concerned with certain properties of works of art. It is not always fully realised that there have been these two quite different conceptions of aesthetics - and just how different they are. In fact, attempts are sometimes made to run them together.

3 The papers brought together by C. Barrett as Collected Papers on Aesthetics, Oxford, 1965, are in fact almost entirely devoted to the philosophy of art, and will serve to illustrate its range. I am very obviously suggesting a new distinction rather than relying on a well-established one when I distinguish sharply between 'aesthetics' and 'the philosophy of art'. But the distinction is to my judgement, essential if my problem of relating philosophy to the discussion of works of art is ever to be cleared up. 
For example, in his volume of readings Problems in Aesthetics Morris includes a selection from Plotinus to which he gives the heading Art as Beauty. This might suggest that Plotinus was taking a particular view about works of art, namely that they were identical with the beautiful - which would have the effect that, for Plotinus, there is no point in raising the question whether aesthetics is about the beautiful or about works of art. When, however, we look at the text of Plotinus we see that he has no special interest in works of art. He begins, it is true, by saying that beauty evidences itself to sight, and he admits that sounds, too, can be beautiful. But he goes on to argue that it is only those persons who restrict themselves to the level of the senses - what Plato calls in the Republic "the lovers of sights and sounds" who take any lasting interest in beatuy at this level. The true philosopher moves on to contemplate the beauty of conduct, of actions, of intellectual pursuits. Above even these, Plotinus continues, there is a loftier beauty still: "That inaccessible Beauty dwelling as if in consecrated precincts, apart from the common ways where all may see, even the profane." Even at the level of sense, furthermore, Plotinus generally takes his examples from natural objects, not from works of art.

For Plotinus, very obviously, aesthetics is about the beautiful and it refers to works of art only in so far as they are a class of objects which sometimes exhibit a (very inferior) sort of beauty. The philosopher who is truly interested in the beautiful will avert his eyes as rapidly as possible from works of art. Here, of course, Plotinus is following Plato. People are sometimes puzzled about the fact that Plato takes such a high view of the Beautiful and such a low view of works of art. It is not just that beauty is a form and a work of art a mere particular. Even amongst the forms beauty occupies a superior position and even considered as a particular work of art is an especially lowly thing. This contrast is particularly obvious in the Phaedrus. Grading the highest types of man, Plato puts first "the man of philo- 
sophical and general culture, especially fond of beauty" but "the poetic man" concerned with representative arts comes only sixth, well below merchants, gym-instructors, and so on. From Plato's point of view the lover of beauty will not be much interested in works of art. This is, I suspect, still true; people who talk a great deal about 'Beauty' are rarely art-lovers.

In Plato's Hippias, Hippias, on being asked what is the beautiful, replies "Why, a beautiful girl is beautiful." (In the article on Beauty in his Philosophical Dictionary Voltaire writes: "Ask a toad what is beauty.. and he will answer 'his she-toad'." A modern Socrates addressing the same question to a modern Hippias would get, I think, much the same sort of answer. It is very natural to speak of a girl as beautiful, as also of a beautiful sunset, a beautiful view, a beautiful country - 'Switzerland is a beautiful country' a beautiful nature, or of a beautiful specimen in a museum, even a pathological museum. It is true that the adjective 'beautiful' is also applied to works of art: coming out of a cinema somebody may say 'that was a beautiful film, I cried all the time', and there is a well-known architectural phenomenon 'the house beautiful'. 'Beautiful' is particularly applicable, although not now uniquely so, to visual objects: as late as 1750 Christopher Write defined the beautiful as "what gives pleasure to the eye": the German 'Schön' is etymologically linked with 'scheinen.'

On the other hand, it would be very odd indeed to describe Crime and Punishment, or even Hamlet, as beautiful, and even in the visual field this adjective is not very naturally applied to Goya's Civil War drawings or to a great many other works of pictorial works of art. It is largely confined to the graceful or the decorative. "When a work has profound vitality", writes the sculptor Henry Moore, "men do not connect the word Beauty with it."4 It has often been used in the description of works of art to mean some

4 Unit One, as quoted in Osborne, Theory of Beauty, p. 14. 
sort of ornamental decoration: in the 18th century our attention is directed to the beauties of a poem, not to its beauty. Although Kant defines aesthetics as a theory of beauty, he admits as exhibiting pure beauty only what we might well think of as very inferior works of art - fantasias, ornaments, free decorations.

It is clear, then, that if aesthetics is concerned with the beautiful, in any ordinary sense of the word, it may draw certain of its examples from works of art but it will not take any special interest in them. Of course, it would be a very queer sort of inquiry, if, as sometimes seems to be supposed, it had as its whole purpose an attempt to offer a definition of the beautiful - as if biology did nothing else than try to define 'being alive'. Presumably it would investigate species i.e., it would contain sections on the beautiful in painting, the beautiful in literature, the beautiful in natural objects. To some degree this is what Kant does in the Critique of Judgment. Although he sets out in search of a definition and constructs his critical argument toward the at. tempt to arrive at one, he goes on to consider types of the beautiful as it manifests itself in different settings, adopt. ing, for example, an unenthusiastic attitude to music on the ground that it disturbs one's neighbours.

Books still appear under the title"Theories of Beauty", but a general dissatisfaction has developed, I should say, with the conception of aesthetics as the theory of the beautiful, and for a number of reasons:

(1) Its association with metaphysical idealism, as in Plato and Plotinus, and the general tendency of discussions of the beautiful to develop into highflown nonsense - the sort of thing which has given aesthetics a bad name.

(2) Its tendency, on the other side, in reaction from metaphysics to collapse into the defence of some such general formulae as the beautiful is what pleases us even although it brings us no profit', which do not seem to have any but a lexicographical interest.

(3) The growing recognition that there is no real reason 
for making a field of inquiry turn around the beautiful. Why not equally around the charming, the delightful, the peaceful? Coupled with this, the recognition that even if one did thus extend the field of aesthetics, one would still be left with a form of inquiry which might be interesting to dictionary-makers, but scarcely to anybody else. For these expressions are used to refer to a miscellaneous range of heterogeneous objects; there is no interesting general connexion to be uncovered by considering more closely the cir. cumstances in which we call something charming rather than beautiful, graceful rather than charming.

We can modulate to the doctrine that aesthetics is about works of art, not about the beautiful in general, by considering what Osborne says in his Theory of Beauty. He there distinguishes what he calls the 'descriptive' from the 'normative' sense of the beautiful. In our recent remarks, he would say, we were talking about the beautiful in its 'descriptive' sense, and he would agree with us that there is nothing in particular to say about the beautiful in this sense except a few lexicographical remarks. But 'beautiful', he suggests, has also a 'normative' sense in which it means 'the characteristic excellence of works of art' and this, he says, is the 'aesthetic' use of the word 'beautiful'. It is not altogether clear why Osborne presumes that his use of 'beautiful' is normative. But I take it he means something like this: There is a use of beautiful in which it is a judgment on and not merely about a work of art that it is beautiful: it is a way of grading the work of art.

Consider first two relatively small points:

(1) Why the characteristic excellence rather than the characteristic excellences? This seems to be a relic of the view that aesthetics is concerned with one property only. But there does not seem to be, on the face of it, any reason whatever for supposing that this is so - there are a great many different adjectives which we apply to works of art as modes of judgment on it. Nor does there seem to be any reason for supposing that whereas beautiful has a normative use 
as well as a descriptive one, these other predicates - charming, elegant, delightful - have only a descriptive use. So let us modify Osborne's definition to begin with, by saying that aesthetics is concerned with the characteristic excellences of works of art.

The next point is that judgments on works of art are by no means always favourable. Would not aesthetics need to be about characteristics such as 'sentimental', 'tawdry', 'flowery' quite as much as 'beautiful', 'charming', 'great'? The original definition must surely be amended to read 'aesthetics is about the characteristic excellences and the characteristic defects of works of art'.

Why does Osborne say the 'characteristic' excellence, rather than the 'excellence' simply? Well, it is obvious that we can ascribe all sorts of excellences to works of art. Consider:

'That painting will fetch a high price.'

'That painting is an excellent souvenir of Australia.'

'That painting is an excellent reproduction of the appal. lingly bad original.'

'That painting is an excellent example of just how bad Victorian painting could be.'

'That painting gives you an excellent idea of what Sydney used to look like.'

'That painting is guaranteed not to fade.'

'That painting goes excellently with the colours in my sitting-room gardens.'

'That painting is an excellent concealment for my wallsafe.'

'That painting is an excellent advertisement for the Grand Canyon.'

'That painting is an excellent piece of political propaganda.'

'That painting is an excellent soporific.'

Is aesthetics about all these forms of excellence? Most aestheticians would certainly deny this; indeed they would 
say it is not about any of them. This firm negation might be based on either of two grounds:

(1) These judgments do not employ as their predicates the 'characteristic' excellences of work of art.

(2) These judgments are not about works of art at all.

What would the grounds be for (1)? In denying that these excellences are 'characteristic' what would be meant, presumably is that objects which are not works of art can be excellent in all these ways. They can fetch a high price, be excellent souvenirs, excellent copies, excellent biographies, give you an excellent idea of what Sydney used to look like, be guaranteed not to fade, go well with the colours in the sitting-room, conceal my wall-safe, advertise the Grand Canyon, be excellent pieces of political propaganda without being works of art at all. But is this really true? Could anything, except a work of art, be an excellent reproduction of an appallingly bad painting, or an excellent example of how bad Victorian art can be? More seriously still: are there, in this sense of the word, 'characteristic' excellences? Are there excellences peculiar to works of art? The traditional approach to aesthetics which said it is the theory of the beautiful denied that there are excellences peculiar to works of art; it presumed that aesthetics was concerned with excellences which are common to works of art and to certain classes of natural objects, e.g. that the excellence of a landscape is the same sort of thing as the excellence of a painting.

To take the opposite view has become more rather than less difficult as a result of recent developments in art. There have been several expositions of objets trouvés - in which what we are to consider critically is a twisted bough, a stone, or some other natural object. The activity of the artist is restricted to finding the object and putting it in a museum; but he himself, presumably, recognised its excellence when he saw it and had it put in a museum. And we are being 
asked to consider it precisely as if it were a piece of sculp. ture.

Certainly, again, it is very natural to judge the excellence of a landscape in terms very similar to those which we might use in judging an example of plastic art. Oscar Wilde once wrote in The Decay of Lying: "My own experience is that the more we study Art, the less we care for Nature. What Art really reveals to us is nature's lack of design, her curious crudities, her extraordinary monotony, her absolutely unfinished condition." But even to put the matter thus is still to judge nature, even if unfavourably, in plastic terms.

It is, in short, more than doubtful whether we can mark off any class of excellences as peculiar to works of art. Those excellences which they do not share with natural objects, they seem to share with any objects of skill: such excellences as being well made, well designed and so on. There $d o$ seem to be excellences, certainly, which are peculiar to given art forms e.g. if somebody says 'the characterisation is excellent, the dialogue superb, the story moved at a fast pace,' he must, so far as I can see, be talking either about a work of literature or about a film. (It might be the case that sculpture shared characteristic excellences with such natural objects as stones, shells, boughs of trees, but not with music.) But whether there are characteristic excellences of works of art as a whole is quite another matter.

Are we to say, then, that aesthetics is about all the excellences of works of art, about what kinds of works of art are the best soporifics, fetch the best prices, go best in the sitting-room? That is a conceivable position, but one which, I think, goes against the grain. We have at least a strong inclination to believe that there are artistic excellences which are different from economic excellences, which do not include, for example, saleability.

That, I take it, is why Croce and after him Collingwood proceeded in a quite different way - following up the se- 
cond of the possibilities I mentioned above. They would say the judgments of excellence listed above are not about works of art at all. When, on their view, we say 'That painting will fetch a high price' we are not talking about the work of art but only about a physical object; works of art are not the sort of thing that can be bought or sold, although first folios, manuscripts, lumps of marble, can be. Most of the other judgments in the list depend upon treating as a work of art what is really, on the Croce-Collingwood view, a 'work of amusement' or a 'work of magic' - the first being the sort of thing that can be a copy, a souvenir, a soporific, and the second the sort of thing which can be an excellent piece of political propaganda, such as a piece of music which inspires martial moods.

Collingwood is not, I should make clear, using "works of art' to mean 'good works of art'. He is not saying that Hamlet is a good work of art whereas the Sherlock Holmes stories are bad works of art; he is denying that the Sherlock Holmes stories are works of art at all. Good and bad can be distinguished, on his view, within amusement and magic as well as within works of art. We can have a good detective story and a bad detective story; a good representation of a scene and a bad representation of a scene; a good piece of propaganda and a poor piece of propaganda; a stirring piece of martial music and a dull piece of martial music - and then we can have a good work of art and a bad work of art. To express the distinction in terms of our modified version of Osborne's definition, the characteristic excellences and defects of a work of art are quite different from the characteristic excellences and defects of a work of amusement or of magic. It is a defect in a work of amusement if it sends you to sleep, it might be a defect in the reader, if he is sent to sleep by a work of art; although it is a defect in a work of magic if it doesn't move or stir you in the desired direction, this is not a defect in a work of art.

In the Croce-Collingood theory, then there are involved 
two different kinds of distinction. The first is a classificatory distinction between works of art, works of amusement, works of magic; the second is an ontological distinction between works of art and physical objects. The first of these distinction has the effect of considerably limiting the range of aesthetics. It has commonly been presumed that as a result of studying aesthetics, we would have something definite to say, even if something deprecatory, about the aesthetic defects of, for example, a piece of martial music - not just that it isn't a 'work of art' but that it suffers from certain specifiable weaknesses as music. If Croce and Collingwood are right this is an illusion. Presumably we have to turn elsewhere, to some kind of amusement theory, perhaps, if we wish to explain why Offenbach's light operas are superior to Lehar's.

The ontological distinction is even more debatable. It is. of course, not only a plausible but an obviously correct view that a first folio Hamlet is not identical with the play Hamlet, and that to say that such a folio would fetch a high price. or is very rare, or is an inaccurate text, is not to make these same comments about Hamlet. More generally, it is obvious that Hamlet is not identical with any particular set of, or a class of similar, marks on paper. It is considerably less obvious, however, that St. Paul's Cathedral is not identical with the physical object which we see before us in London, or a landscaped garden with an arrangement of trees, shrubs and lakes.

Let us see where we now stand. I have drawn attention to six possible views about the field of aesthetics. There are, no doubt, other possibilities, but these six will serve to illustrate my main point:

(1) Aesthetics is concerned with the nature of the beautiful in general and with works of art only in so far as they sometimes exemplify the beautiful.

(2) Aesthetics makes discriminations within a general class of predicates - all of them 'felt to be' aesthetic - the 
charming and the repellent, the sublime and the ugly, and many more such predicates.

(3) Aesthetics is concerned with the characteristic excellences and defects of these objects which are normally thought of as being works of art.

(4) Aesthetics is concerned with any excellences and defects which it is proper to ascribe to what are normally thought of as being works of art.

(5) Aesthetics is concerned with the characteristic excellences of works of art, but only in a special, redefined, sense of 'works of art'.

(6) There is no field of inquiry aesthetics, as distinct from literary theory, musical theory, architectural theory, on the one side, and the philosophy of art on the other.

What $I$ have done in this paper is to give some reasons for rejecting the view that there is such a subject as aesthetics in any of the five senses of the word particularised above. Of course, it is, in part, a matter of choice how we use the word 'aesthetics'. Lexicographers, for example, distinguish between the predicates 'beautiful', 'charming', delightful'; what they do could no doubt be better done and the result, if you like, could be called 'aesthetics'. But certainly philosophers would be not of great help in this task, and the results would scarcely satisfy the traditional aspirations of aestheticians.

I shall express my conclusions in a downright way by saying: 'There is no such subject as aesthetics.' This must now be taken to mean: "There is nothing illuminating and non-lexicographical to be said about the nature of the beautiful in general' and there are no defects and excel. lences peculiar to, and common to, all works of art." I do not pretend to have demonstrated these conclusions, and they involve the sort of negation which it is extremely difficult to demonstrate. It will follow, if I am right, that philosophy has nothing to contribute to aesthetics except its destruction. But this conclusion is less alarming than it at first 
sight seems. For there certainly is, I am suggesting, such a subject as the philosophy of art. It is possible, and desirable, to discuss such questions as the ontological status of works of art - although it should not be presumed that the answer to 'What is the ontological status of St. Paul's Cathedral?' will necessarily be identical in its general form with the answer to 'What is the ontological status of Hamlet?' - or those many other questions which, as I have suggested, form part of the philosophy of art. But one will do so more sensibly once the philosophy of art, thus understood, has been distinguished from that other enterprise of defining beauty or of discovering the characteristic excellences of works of art with which it has so often, and so unfortunately, been confused. 
Se trata de exponer algunas razones para rechazar el punto de vista de que hay una disciplina llamada estética que posee su propio campo de investigación como distinto de la filosofía del arte, por un lado, y de la teoría literaria, musical o arquitectónica, por otro. Para aclarar la situación derivada de los diversos intentos de desarrollar una estética independiente, es preciso distinguir:

(1) juicios que asignan predicados criticos a obras de arte o a artistas particulares: "El Rey Lear es una gran tragedia." "Stravinsky es un maestro de la orquestación."

(2) juicios acerca de formas de arte específicas: "Toda gran tragedia tiene que ver con la perfidia." "La pintura capta la forma de los objetos naturales."

(3) juicios acerca de las obras de arte en general: "Toda obra de arte significa un contenido a través de su forma." "Toda obra de arte tiene un comienzo, un medio y un fin."

(4) juicios que asignan predicados peculiarmente filosóficos ya sea a las obras de arte ya a comentarios críticos sobre las obras de arte: "Hermoso es un predicado relacional." "Los juicios estéticos son exhortaciones disfrazadas."

En adelante se considerarán distintos modos de actividad, distinguiendo la que emplea enunciados del tipo (1) como crítica; la que emplea el tipo (2) como teoria crítica; la del tipo (3) como estética; y la del tipo (4) como filosofía del arte. Lo que no quiere decir que tales tipos de juicios se den separados en la práctica con todo rigor. Por ejemplo, los teóricos de la crítica defienden sus teorías haciendo juicios críticos sobre obras de arte particulares; y los que se dedican a estética no pueden evitar caer dentro de la teoría crítica y aún de la crítica misma. Y en la dirección contraria, la crítica resulta conducida dentro de la teoría crítica, aunque no tenga que acontecer así necesariamente. Lo que es más discutible es que la crítica deba llegar hasta la propia estética considerada como un campo distinto. Pero para nuestros propósitos inmediatos, la distinción fundamental se da entre los primeros tres tipos de investigación -crítica, teoría crítica y estética- por una parte, y la filosofía del arte por la otra. Platón y Aristóteles pueden servir como ejemplos de la diferencia entre filosofía del arte y teoría crítica. Platón fue, tal vez, el primero es discutir lo que se ha llamado "el estatus ontológico de las obras de arte", discusión filosófica que, en principio, no supone extensos conocimientos acerca de las obras de arte. Aristóteles, por 
otra parte, es un teórico de la literatura, aunque incluya a la música en la poesía como era costumbre entre los griegos, pero salvo algún punto ocasional, pudo haber escrito toda la Poética sin especiales conocimientos filosóficos. Se puede concluir diciendo que hay ciertas cuestiones que surgen a propósito del arte $y$ que, por ser esencialmente filosóficas, interesan al filósofo sistemático. Estas cuestiones constituyen la filosofía del arte, no la estética. Sin embargo, el crítico, el teórico de la crítica y el investigador dedicado a la estética, no están más obligados a ocuparse de estas cuestiones que, por ejemplo, el científico dedicado a la física está obligado a sostener un punto de vista sobre el estatus ontológico de los electrones. Naturalmente, además de los problemas tratados por Platón hay muchos otros que pertenecen a la filosofía del arte. Entre otros, aquellos que surgen, ya no de la obra de arte, sino de los comentarios críticos sobre las obras de arte, por ejemplo, los que plantean las nociones de unidad, forma, contenido, creación, imaginación, verdad artística, etc. Nociones acerca de las cuales el filósofo tiene algo que decir. También tiene algo que decir acerca de las razones que se dan para apoyar la afirmación de que una obra de arte es buena o no lo es. El filósofo está particularmente interesado en el estudio de estas diferentes clases de razones.

Hay fundamentos suficientes para aceptar que aquí existe una forma de inquisición que puede ser descrita propiamente como filosofía del arte, paralela a la filosofía de las matemáticas o a la filosofía de la ciencia. Ahora debemos preguntar si hay tan buenas razones para suponer que la estética es un campo de investigación igualmente fructífero. Históricamente hablando hay dos puntos de vista acerca del asunto principal de la estética, si bien no se ha visto con claridad la razón de dos concepciones tan diversas, aunque a veces se haya intentado hacerlas avanzar juntas. La primera de estas dos concepciones está relacionada con "lo bello"; la segunda, con ciertas propiedades de la obra de arte. Se ha hablado, por ejemplo, de una estética de Plotino, y efectivamente Plotino se ocupa de la belleza pero se refiere a las obras de arte de manera lateral y solamente en la medida en que pueden exhibir, algunas veces, una muy inferior especie de belleza. En este punto Plotino sigue a Platón.

Es muy natural hablar de una bella mujer, de una puesta de sol muy bella y hasta de un hermoso especimen en un museo de patología. Alguna vez se ha dicho que el adjetivo se aplica particularmente a objetos visuales y hasta se ha llegado a definir lo bello como lo que da placer al ojo. Por otra parte, se pueden citar algunas de las mayores obras en la historia del arte -cuadros de 
Goya, por ejemplo-, que ciertamente resultaría extraño describir con aquellos adjetivos. Kant define a la estética como teoría de lo bello, pero a pesar de esto admite como muestra de belleza pura solamente ciertas obras -fantasías, ornamentos, decoraciones-, que nosotros tendríamos por obras de arte inferiores. En consecuencia, es claro que si la estética tiene que ver con lo bello en el sentido ordinario de la palabra, podrá usar como ejemplos algunas obras de arte pero no tomará en ellas especial interés. Además, la estética resultaría ser una curiosa clase de investigación sí, como algunas veces se supone, redujera su objeto en total al intento de ofrecer una definición de la belleza. Sería tanto como si la biología no hiciera otra cosa que definir el ser vivo. Probablemente la estética también investigaría especies y acabaría por dedicar secciones a lo bello en la pintura, en la literatura o en los objetos naturales. En cierta medida, esto es lo que hizo Kant.

De manera general, la insatisfacción frente a la estética definida como teoria de la belleza obedece a cierto número de razones:

1) Su asociación con el idealismo metafísico y su tendencia a discusiones sobre lo bello desarrolladas dentro de la más amplia falta de sentido;

2) su tendencia, por otra parte, a defender fórmulas generales que no tienen sino un interés lexicográfico, como aquella de que "lo bello es lo que nos place aunque no nos traiga ningún beneficio";

3 ) el reconocimiento creciente de que no hay razones para hacer un campo de investigación acerca de lo bello.

Puede sostenerse que la estética se ocupa de las obras de arte y no de la belleza en general. Osborne distingue lo que llama el sentido "descriptivo" del sentido "normativo" de lo bello. Podría decir Osborne que en los párrafos anteriores hemos empleado el término en su sentido descriptivo y estaría de acuerdo en aceptar que esto no tiene más interés que el lexicográfico. Pero añadiría que, usado en su sentido normativo, lo bello significa la excelencia característica de las obras de arte. No es muy claro por qué Osborne supone que el uso que hace del término es normativo, pero tal vez quiere decir algo como esto: hay un uso de bello en el cual se hace un juicio sobre una obra de arte que es una manera de graduarla. Pero aquí hay que considerar dos puntos: (1) Hablar de excelencia y no de excelencias parece una reliquia de la concepción de la estética como estudio de una sola propiedad. Sin embargo, hay un gran número de adjetivos diferentes que se aplican a las obras de arte como modos de juicio sobre ellas y habría que aceptar que tienen también un uso normativo. (2) A esto habrá que añadir que los juicios sobre obras de arte no siempre son 
favorables, lo que obligaría a considerar todavía otros adjetivos que se refieren a los defectos característicos de las obras de arte.

Pero cabe preguntar: ¿hay excelencias peculiares o características de las obras de arte? El punto de vista tradicional de la estética como teoría de lo bello lo niega, puesto que supone que ciertas excelencias son comunes a las obras de arte y a cierta clase de objetos naturales. Por otra parte, el punto de vista contrario es bastante difícil de sostener dados los desarrollos recientes en arte, en que a veces la actividad del artista se limita a encontrar el ob. jeto y llevarlo a un museo. Ciertamente es bastante dudoso que podamos señalar alguna clase de excelencias como pecualiares de la obra de arte considerada como un todo. Puede ser que aquellas excelencias que los obras de arte parecen no compartir con los objetos naturales, sean compartidas con otros objetos creados por la habilidad humana. Sin embargo, Croce y Collingwood defendieron el segundo punto de vista, para lo cual establecieron dos distinciones diferentes. La primera que clasifica las obras de arte separándolas de las obras de magia y de las de diversión, con lo cual limitan considerablemente el rango de la estética. La segunda, todavía más discutible, es una distinción ontológica entre obras de arte y objetos físicos, nada fácil de justificar cuando decimos, por ejemplo, que la catedral de San Pablo como objeto arquitectónico no es idéntica con el objeto físico que nosotros podemos visitar en Londres.

Se ha llamado la atención acerca de seis puntos sobre el campo de la estética, que desde luego no son los únicos posibles pero ilustran el punto de vista del autor. La Estética (1) se relaciona con lo bello en general y con las obras de arte sólo en la medida en que a veces ejemplifican lo bello; (2) hace discriminaciones dentro de una clase general de predicados; (3) se relaciona con las excelencias y los defectos característicos de las llamadas obras de atre; (4) se relaciona con cualquier excelencia o defecto de las llamadas obras de arte; (5) se relaciona con las excelencias características de las obras de arte, pero solamente en un cierto sentido de "obras de arte"; (6) finalmente, no hay un campo de investigación estética en ninguno de los cinco sentidos acabados de señalar.

El autor no pretende haber demostrado sus conclusiones, porque esta clase de negaciones son extremadamente difíciles de demostrar. Pero si aquellas son ciertas, la filosofía no tiene nada que contribuir a la estética excepto su destrucción. Aunque esta última conclusión puede ser menos alarmante de lo que parece a primera vista, porque el autor sugiere que muchas de las cuestiones apuntadas sean tratadas como filosofía del arte. 